\title{
Study on the Concept of Pluralistic Musical Culture in Chinese Vocal Music
}

\author{
Tao Liu \\ Xiamen University, Xiamen, Fujian, China, 361005
}

Keywords: Chinese vocal art, one polar, pluralism

\begin{abstract}
Under the background of diversified times, the development of Chinese vocal music shows its outstanding characteristics. This paper expounds the development of vocal music in China, examines and studies the process of the formation and development of vocalism in China, and at the same time, explores the profound influence of social trends such as the protection of intangible cultural heritage and the development of cultural industries on the vocal arts in China.
\end{abstract}

\section{Introduction}

"Yuan" has two basic meanings in Chinese characters: 1. The first thing. 2. The basic things. The two seemingly contradictory concepts just explain the law of the development of the cycle of change in all things in the world. The so-called "one dollar, Vientiane update", this "Vientiane update" is what we call today diversity. The vocal art of China follows the path of its growth, from the formation of "one polar" to the development of "pluralism."

\section{A Review of the History of Vocal Music in China}

Traditional Chinese vocal music can be traced back to the period of Yanhuang. Zhao Ye's "Spring and Autumn Annals of Wu Yue" in the Eastern Han Dynasty recorded a folk song "Dancing Song" depicting the hunting of ancient people. Only the character "Brokeback Bamboo, Bamboo, Fly, Vivid and concise, reflecting the spontaneous singing of ancient people when tense work. The Zhou Dynasty established the "ritual and music" system, the "ceremony for the sake of music" and the prosperity of the nation, and the establishment of music leading agency "Da Shi Le", vocal music at this period has accompaniment and without accompaniment, sing and harmony. The Qin and Han dynasties established "Yuefu", "Bocaizhuan, Gongyinji", collected a large number of folk poetry to make fun, the north to "phase harmony song" mainly used for military music, ceremonies; Reflect the love of children, daily life. Since then, in the successive dynasties, with the development of social economy and culture, the development of vocal music in China has added new elements. Tang Daqu changed the "single word" line cavity, became the "single word multi" sound, the lyrics developed into the sentence combination of the length of the phrase, making the tune more innovative and fluid. Song $\mathrm{Ci}$ is a combination of literature and music in the form of singing, poetry coupled with music called the song melody, is a combination of music and singing art of new developments. Yuan Sanqu and Yuan Zaju together constitute the two genres of "Yuanqu". Sanqu Song is a combination of music and poetry, which is used for lyricism, writing scenery or narrative, while Zaju is a collection of literary drama, music, art and role playing and other arts as one of the integrated arts, is a symbol of the maturity of Chinese opera. The Ming Dynasty and the South Dynasty storytellers, the northern drums have formed regional characteristics, resulting in genre singing, South opera "Four Voices" and local opera combined and influence each other, and gradually formed Beijing Opera, Kunqu Opera, Hui Opera and other local operas.

Vocality and Performing Arts in Modern and Contemporary China with the reform of social politics and economy, vocals and forms reflecting the style of the times have emerged in every particular historical period. "School music" is the cultural phenomenon brought by the enlightenment movement of bourgeois democracy before and after the Revolution of 1911. From the early lyric writing to subsequent independent writing, its significance lies not only in cultural psychology but also in changing the traditional Chinese aesthetic music Ideal and fun, but also 
marks the end of the ancient Chinese traditional music stage, the arrival of the new music and culture era. During the May 4th Movement, a group of composers engaged in professional music creation held high the banner of the New Culture Movement and began to use Chinese compositions to create Chinese-style songs. Chinese art songs came into being. During the War of Resistance Against Japan, singing songs of salvation helped promote the development of mass songs. Nie Er, Xian Xinghai, He Luting and other composers played the strong voice of that era. The operas and film episodes that were born in the period of New Democracy led the creation and dissemination of songs, reflecting the real life, ideology and love of ordinary people at that time. In the early days of socialist construction, the adaptation of folk songs, carols and model operas produced under certain historical conditions was still sung by people as a classic red song so far, and the mark of the culture as a special period will never be emaciated. Since the reform and opening up to the outside world, the vocal arts in China have developed in all directions in three dimensions: popular songs, belcanto, new folk music, rock and roll folk songs, trilogy, cross-border singing, musical theater, Concepts, new disputes emerge in an endless stream.

\section{Difficult Journey from Diversity to One Polar}

Looking back at the development of vocal music in China, it is not difficult to see that "many blood qualities" are the characteristics of Chinese vocal music. With its vast territory, numerous ethnic groups and complex languages, the changes of the dynasties make the traditional Chinese vocal music a complex and diverse branch of arts that has led to the development of Chinese vocal culture Broad and not refined, difficult to establish unified. Why did we come up with the "five-phase law" as early as the Warring States period and never established a systematic music and sound system? Why Qin and Han Dynasties Yuefu songs, the court Sui and Tang Dynasties did not evolve into a progressive evolution of vocal singing voice system? Although these have become a historical reflection, they still have some reference for the future development of vocal music in China. The unitary meaning in this article refers to the development of vocal music from spontaneity and diversity to a systematic and scientific development. The vocal music in China gradually became unitary in the first half of the twentieth century.

From the perspective of vocal education, bourgeois enlightenment thinkers led by Liang Qichao put forward: "Gail wants to transform the quality of the people, poetry music is one of the most important elements of spiritual education", spare no effort in developing music education in schools, and a group of overseas specialists or part- Music intellectuals (such as Xiao Youmei, Li Shutong, Gao Shoutian, Feng Yaxiong et al.) Organized music societies, organized music workshops, promoted "new music" and wrote "school music." In 1927, Xiao Youmei founded Shanghai National Music Institute, the first complete music education institution in modern China, which lays a good foundation for the development of modern music and culture in China.

From the genre of vocal music art, the democratic spirit and revolutionary ideology of the early twentieth century have filled in new words in traditional folk songs and developed into new folk songs. Folk rap has also entered the prosperous city from vagrant, Kinds of Chinese original art songs that evolved from "school music" to "open source" have left us plenty of questions like "Q", "How do I not want her", "Three wishes of the rose", "I live in the Yangtze River" The flowering of audiovisual films provided a prosperous stage for Chinese film songs in the 1930s and provided a new platform for the creation and dissemination of songs. Outstanding films all had a good theme song or episode, "Fishing song", "spring", "End of the World song girl", "Four Seasons song" became the popular songs; opera by the early children's musical "sparrows and children" to "drama plus singing" "Yangtze River storm" , And then to borrow the form of European opera "Autumn", eventually "White-Haired Girl" as a milestone, marking the Chinese opera art finally found their own independence Opera road of development, the formation of distinctive artistic features.

From the perspective of the development of vocal music technology, although the vocal techniques are abundantly expounded in the traditional Chinese singing theory, there are illustrations of the singing effect, ; From aesthetics point of view, such as "Music Notes - Teacher B articles" reads: "The ancient song who, such as resistance, such as falling like a song, such as 
folding, static as alder, middle, sentence in the hook"; also discussed The causal relationship between sound and love, such as Liu Xuan "Wen Xin Diao Long" made it clear: "Poetry is happy heart, the sound is the body of music, music in the body, drum masterpiece, heart in poetry, gentleman Yi Zheng its article. "These vocals are all treasures of Chinese vocal culture. However, at the beginning of the 20th century, the vocal technology of vocal music in China actually continued to evolve. The method of vocal music training of native folk songs and operas based on local dialects did not form a unified and standardized method of vocal music that followed the physiological rules of body vocalization. At this point, the European and American vocal musicians apparently took a step ahead of us. The Belcanto vocal music training methods and theories, which were gradually perfected and developed from the Renaissance, have reached maturity through religious Divine Comedy, Baroque music, romantic feelings and many times in the opera era. Beginning in the 1920s, Chinese vocal students represented by Zhou Shu'an, Ying Shangneng and Zhao Meibei returned from their studies in Europe and the United States, and taught vocals and music in schools throughout China. In the name of Sulin Shilin, Mrs. Smith and Italian wife Sai Yee $\mathrm{Li}$ as the representative of foreign vocal teachers are also taught in Beijing, Shanghai and other places. They trained China's first generation of local vocal music talents, such as Yu Yixuan, Sisi Gui, Xie Shaozeng, Lang Yuxiu, Zhou Xiaoyan, Shen Xiang and Li Weibo, etc. These vocal music predecessors or overseas study or teaching in China are the technological development of Chinese vocal musi, Education popularization made outstanding contributions.

At this point, the vocal arts in China have prepared vocal education institutions, perfected vocal genres, and trained a group of vocal technicians. The vocal arts in China have entered a relatively systematic and scientific initial stage.

\section{The Inevitable Evolution from One Polar to Pluralism}

"The one polar, Oshii also." The process of the unity of Chinese vocal art, along with the evolution of the social form of new China, in the contradictions, conflicts and differences to convergence, interaction and development. In the early years of the founding of New China, the controversy over the throat of "earth" and "ocean" established a programmatic definition of the development of Chinese national vocal music. In early 1957, the "National Vocal Teaching Conference" was held to raise the issue of "nationalization" of the traditional singing style in Europe. The so-called "nationality is to save and preserve the basic characteristics of traditional singing in Europe and all its outstanding achievements. On the basis of expressing the language, style and thoughts and feelings of our nation, we should strive for its thoroughness and perfection so as to truly enjoy and enjoy the vast masses of our country. Since then, the Chinese national vocal music has gradually found out a set of sound teaching and performance systems on the road of keeping the tradition and adopting foreign ideas, forming today's Chinese national singing style. Since the 1980s, the reform and opening up brought about changes in the public ideology. Popular songs approached their lives with lively melodies and emotional realities. Their performances began to flourish in people's lives. After typhoon, northwest wind, rock style and ballads Wind, Europe and the United States, the original wind, karaoke wind, MTV wind, wind network, combination of wind, super wind, grassroots wind, formed a pop-singing popular style. With the increase of exchanges both at home and abroad, internationally renowned vocal masters came in to bring forth intuitive and exquisite singing skills and orthodox vocality concepts. The vocal students in China went out and dabbled in the vocal and cultural atmosphere of Europe and the United States, accumulating knowledge, Comprehension style, experience honed, China's voice of the United States gradually reached the internationally accepted standards, and was accepted by the Chinese people. At the same time, the academic debate on "Three Singing Methods" has been fruitless and inconclusive since the eighties of last century. As the audience of CCTV Youth Songs increased, the debate has so far been fruitless and in fact the " Three Singing "controversy itself is the manifestation of diversified development of Chinese vocal art in theory, creation, singing technique and aesthetic conception. Behind the controversy is the burst of people's thinking and the collision of concepts in the process of China's modernization. The result of the collision leads to individual It 
is a virtuous circle of diversified development that the culture itself constantly improves and develops. Individual cultures promote each other, push each other toward harmony. In fact, the reverberations of the "three singing methods" have remained unresolved. New phenomena such as "vague definition," "cross-boundary singing," and "original singing" have also emerged. The maturity of one polar is diversified. This is an inevitable trend in the development of vocal music in China.

\section{Protection of Cultural Heritage Produces a "Diversified" Vocal Culture}

As a multi-ethnic country with a long history and profound cultural heritage, China's cultural heritage contains the unique spiritual values, modes of thinking and imagination of the Chinese nation, embodies the vitality and creativity of the Chinese nation and is the crystallization of the wisdom of all ethnic groups. The treasure of all human civilization. Folk music in China is a rich treasure house of resources. Singing methods and forms of various national songs are an important part of the musical cultural heritage. For example, Humahu and Ningxia Huayu in Inner Mongolia all reflect the unique cultural characteristics of ethnic groups Multivariate style. In order to implement the 16th National Congress of the Communist Party of China on "supporting the protection of important cultural heritages and excellent folk art" and fulfilling our country's obligation to accede to the "Convention for the Safeguarding of the Intangible Cultural Heritage" of UNESCO, the State Council has promulgated the "Opinions on the protection of material and cultural heritage." Through the protection of non-material cultural heritage and the inheritance and development of outstanding traditional ethnic cultures, the pride, confidence and cohesion of the Chinese nation will be greatly enhanced, the cultural quality of the entire nation will be enhanced, the healthy cultural ecology will be protected, and the social and economic development of our country and culture and other undertakings play a full, coordinated and sustainable development play a major role.

As China officially started the work on strengthening the protection of intangible cultural heritage in our country, more and more people began to pay attention to Chinese folk music. The most typical example is the "original" folk songs into the television media, such as CCTV's "Folk Song • China" section, "Charm 12" section; Inner Mongolia TV's "Music Tribes" section, Guangxi Satellite TV "sing songs" section, Shanghai Satellite TV's "Sea Echo" section and so on. The "original" folk song has become the focus of attention of all people. At the same time, it also arouses the people's love of folk music and the awareness of inheritance and protection. The development of "original ecological" folk songs that represent the various national characteristics of our country is also preserved. The value of our intangible cultural heritage is also preserved forever. On May 18, 2001, UNESCO announced the first batch of "Representatives of Human Population and Intangible Heritage" in Paris, for a total of 19 items, the vast majority being folk tradition ceremonies declared by developing countries, spoken language and performing arts projects, China declared "Kunqu opera" is also on the list. In 2002, China formally launched the project of "Rescuing and Protecting the Chinese Oral and Intangible Heritage of Mankind" and made remarkable achievements in its practical work: Kunqu Opera, Guqin, Uygur Muqam, Uyghur Tingu (Mongolian traditional long-term tune) Fujian Nanyin, etc. have been approved by UNESCO as "human oral and intangible heritage masterpiece." Both the state's policy support and the establishment of the "original" folk song television program provide a platform for our "pluralistic" vocal music culture to provide a platform for meeting the "diversified" aesthetic needs of the general public. The protection of cultural heritage provides a resource guarantee.

\section{Cultural Industry Development Calls for "Diversified" Vocal Culture Innovation}

UNESCO's definition of a cultural industry is: "A cultural industry is a series of activities that produce, reproduce, store and distribute cultural goods and services in accordance with industry standards." The cultural industry has the characteristics of low resource consumption and high added value, which is of great significance for optimizing human living environment and improving 
people's overall quality for building a conservation-oriented society and a sustainable society. In our country, vigorously develop the cultural industry has been written into the central document, the cultural industry has become an important part of China's economic and social development strategy. Vocal culture, as an important part of cultural industries, should also form a multi-vocal culture that meets the characteristics of the times.

Cultural industry is a broad concept of rich connotation. It includes performances, film and television industry, culture and entertainment industry, cultural tourism industry, internet culture industry, art industry, culture and education industry, art training industry and culture exhibition industry. Industrial chain. The complexity of the structure of the main body of cultural industries requires a wide range of vocal cultural products to meet various aesthetic and consumer needs. At the same time, the cultural industry advocates creativity first, and the core driving force of the cultural industry is creativity. It emphasizes that a main cultural or cultural factor relies on individuals (teams) to develop and market intellectual property through technology, creativity and industrialization. Therefore, Aesthetic concepts, art forms, means of communication, market changes and consumer service awareness should be innovative. In addition, the development of cultural industries is the need of national cultural security and the embodiment of cultural soft power of countries and regions. It is also a strategic need that concerns the survival of nationalities, the export of value and the cultural inheritance. This also requires vocal cultural workers to keep pace with the times, not only to improve their artistic standards, combined with the cultural industry market, but also to inherit the Chinese culture, enhance the competitiveness of Chinese culture for the purpose of developing innovative vocal culture, with a global Thinking and Vision Respond to the Opportunities and Challenges in the Globalization of Cultural Exchanges.

\section{Conclusions}

In short, with the rapid development of the times, the exchanges between countries in the world will deepen. The exchange and integration of multi-ethnic vocal cultures will promote the further prosperity of the world's vocal culture. We believe that through our unremitting efforts, the vocal arts in China will certainly form one Prosperity and diversification of the situation, China's music culture will certainly stand strong in the world of music and music forest.

\section{References}

[1] Hu Yuqing. Chinese and foreign vocal history [M], Chongqing: Southwest China Normal University Press, 2000, p. 204.

[2] Guo Kejian. Tracking and Reflections on the Hot Issues of New Chinese Vocal Academic [J], Music Studies, No.3, 2010, p. 63.

[3] Qin Zhigang. Strive to build a total spiritual home of the Chinese nation [N], China Art, 2008-04-04.

[4] Fan Zuyin. Reflections on Several Issues Concerning the Safeguarding of Intangible Cultural Heritage [J], Music Studies, No. 1, 2006, p.

[5] Zhang Jiangang. Several basic logic of the development of cultural industries [J], South Symposium, 2003, No. 2, Page 32. 